\title{
Molecular Breeding of Three Genes Associated with Egg Production Traits in Three Strains of Chickens
}

\author{
Waleed S. El-Tahawy ${ }^{1}$ and Manal M. Abdel-Rahman ${ }^{2 *}$ \\ ${ }^{1}$ Animal and Poultry Production Department, Agriculture Faculty, Damanhour University, Egypt \\ ${ }^{2}$ Genetic Engineering and Biotechnology Laboratory, Plant Pathology Department (Genetic Branch), Agriculture Faculty, Damanhour \\ University, Egypt \\ *Corresponding author's Email: mm.rahman@agr.dmu.edu.eg; ORCID: 00000003-0141-1568
}

Received: 10 Nov. 2020

Accepted: 21 Dec. 2020

\begin{abstract}
Breeding programs play an important role in increasing the performance of chickens. The poultry industry regards growth and reproduction as the two most economically valued characteristics for providing adequate animal proteins. Genetic variations are the basis of animal breeding. The present study was conducted on three genes, including Prolactin, 3-Hydroxy-3-Methylglutaryl-Coenzyme A Reductase (HMGCR), and Gonadotropin-Releasing Hormone Receptor (GNRHR). DNA was isolated from 48 chickens taken from three strains Lohmann Brown (17), Sinai (24), and Gimmizah (7) for Prolactin, HMGCR, and GNRHR gene amplification by using the PCR protocol. Electrophoresis was performed on the PCR products and the bands were viewed on a transilluminator. The size of the Prolactin gene, HMGCR, and GNRHR were 154, 675, and $210 \mathrm{bp}$, respectively. For the Sinai strain, five bands for Prolactin, two bands for HMGCR, and six bands for GNRHR were found while for the Lohmann Brown strain, five bands of Prolactin gene, three bands for HMGCR, and five bands for GNRHR were found. Regarding the Gimizah strain, two bands were found for Prolactin and GNRHR genes and there was only one band for the HMGCR gene. The Lohmann Brown strain respectively matured 13 and 91 earlier than Gimizah and Sinai strains with a higher egg number during the first 90 days.
\end{abstract}

Keywords: Breeding, Chickens, Egg production, GNRHR gene, HMGCR gene, Prolactin gene, PCR

\section{INTRODUCTION}

The Prolactin (PRL) gene promoter is highly polymorphic and has significant effects on egg quality traits in poultry (Liu et al., 2010). The PRL is a single-chain polypeptide hormone that belongs to the growth hormone family of genes and is mainly synthesized by lactotrope cells of the anterior pituitary gland of all vertebrates. The PRL gene is detected to be critical for the onset and kept of these reproductive behaviors in birds (Liu et al., 2010). Egg production is the most important feature in layers, which affects the economic benefits of poultry farmers (Wolc et al., 2011). Egg production is the most important trait in layer chickens as it directly influences the benefits of the poultry industry (Zhuang et al., 2019).

Molecular genetics studies the chemical mechanisms of inheritance, as an investigation of the biochemical nature of genetic material and its role in controlling phenotypic structures (Alameri et al., 2019).
3-Hydroxy-3-methylglutaryl-coenzyme A reductase (HMGCR) is a key enzyme for cholesterol homeostasis and catalyzes the rate-limiting step in cholesterol biosynthesis (Goldstein and Brown, 1990). The HMGCR gene directly regulates serum lipoprotein metabolism via a feedback mechanism (Goldstein and Brown, 1990). The HMGCR gene plays an important role during the growth and controls the transfer of primordial germ cells (Van Doren et al., 1998). The HMGCR is an important catalyzing enzyme, which catalyzes the product of 3Hydroxy-3-methylglutaryl-coenzyme A (HMG-CoA) to mevalonate through four-electron oxidoreduction, which are the precursors for the generation of cholesterol in humans and are responsible for the production of ergosterol in plants, fungi, and protozoa (Istvan and Deisenhofer, 2000; Henriksen et al., 2006; Macreadie et al., 2006). Several polymorphisms have been identified in the HMGCR gene locus (Chasman et al., 2004). The HMGCR is indicated to be a logical candidate gene for 
cholesterol metabolism, which is the rate-limiting enzyme in cholesterol synthesis (Xu et al., 2010). HMG-CoA reductase plays a significant role as a resident protein in the Endoplasmic Reticulum (ER) attached to the ER membrane consisting of eight transmembrane segments (Chen et al., 2012).

HMGCR gene is associated with chicken egg production (Han et al., 2014). The chicken HMGCR gene is located on chromosome $\mathrm{Z}$, and also contains 20 exons and 19 introns. The HMGCR gene is important for the animal growth performance and metabolism of cholesterol. Wei et al. (2012) found that there is a relationship between the HMGCR gene and carcass traits, growth traits, and lipid profile in chickens.

Neuropeptide Y (NPY) and Gonadotrophin Releasing Hormone Receptor (GNRHR) are also two candidate genes that play an important role in physiological functions in growth, especially in reproduction processes (Fatemi et al., 2012). Two candidate genes, Gonadotropin-Releasing Hormone I (GNRH I) and Gonadotropin-Releasing Hormone II (GNRH II) play an important role in egg production in chickens (Bhattacharya et al., 2019). The GNRHR is a decapeptide released by the hypothalamus that regulates reproduction in most vertebrates. The GNRHR gene is one of the rhodopsin hormones and is expressed in the pituitary gland, the brain, and testes, spleen, and the heart (Carolsfeld et al., 2000). The GNRHR is related to the total egg production and the age of the first egg. The Gonadotropin-Releasing Hormone $(\mathrm{GnRH})$ stimulates the release of gonadotropins from the pituitary gland through its receptor (Sun et al., 2001).

The production process of the avian egg is controlled by the hypothalamic-pituitary-gonadal-axis (Kuo et al., 2005). However, GNRHRs are mainly associated with the development and function of the reproductive axis in avian species (Bedecarrats et al., 2006). The GnRH binding to its receptor stimulates gonadotropin secretion from the pituitary gland and then induces the steroid production process in the gonads and egg production in chickens (Sonez et al., 2010). The GnRH and its receptor result in the appropriate growth, maturation, and maintenance of the gonads (Dunn et al., 2004). The GNRHR encoded gene is located on the long arm of chromosome number 10 and consists of 4 exons and a length of $2308 \mathrm{bp}$ (NCBI).

The current experiment aimed to evaluate the reproductive traits of three chicken strains, including Lohman Brown, Sinai, and Gimmizah strains, raised in Egyptian environmental conditions. Moreover, three associated genes and related egg production traits were identified.

\section{MATERIALS AND METHODS}

\section{Ethical approval}

The present study was conducted at the Poultry Research unit (El-Bostan Farm), Department of Animal and Poultry Production, Faculty of Agriculture, Damanhour University, Damanhour, Egypt in 2018. This study was approved by the Experimental Animal Ethics Committee of the Faculty of Agriculture, Damanhour University, Egypt.

\section{Husbandry of flocks}

Three chicken strains, including Lohmann Brown (LB), Sinai (SI), and Gimmizah (GM), were raised in Egyptian environmental conditions and were selected for the reproductive traits evaluation. On the day of hatching, all chickens were permanently identified by wing banded and placed in floor incubators for the first week after hatching at a starting temperature of $33^{\circ} \mathrm{C}$ and then reduced by $2-3^{\circ} \mathrm{C}$ every week. All chickens were housed in the same room and had similar management and environmental conditions throughout the experimental period. At 18 weeks of age, the females were placed in individual laying cages $(20 \times 45 \times 40 \mathrm{~cm})$. All chickens were fed ad libitum on a diet containing $21 \%$ crude protein and $2.9 \mathrm{Kcal}$ Metabolizable Energy (ME) $/ \mathrm{kg}$ feed up to 6 weeks of age. They were then given a diet, containing $18 \%$ crude protein and $2.8 \mathrm{Kcal} \mathrm{ME} / \mathrm{Kg}$ feed until they were 18 weeks old. Afterwards, they received a diet that contained $16 \%$ crude protein, $2.75 \mathrm{Kcal} \mathrm{ME} / \mathrm{Kg}$ feed, $3.5 \% \mathrm{Ca}$, and $0.5 \%$ available phosphors during the egg production period. The light intensity decreased from 8-18 weeks of age to $8-10$ hours, after that the light intensity increased to 16 hours per day during the laying period. The chickens were vaccinated against Newcastle Disease Virus, Gumboro, and Fowlpox diseases as recommended. At 30 weeks of age, wing vein blood samples were taken from chickens randomly from each genotype (strain).

\section{Egg production traits}

Age at Sexual Maturity (ASM) was recorded for each chicken, the period from hatching to the day of laying the first egg. The duration of laying time of the first 10 eggs and the weight (EW10) were determined as the number of days each chicken needed to give its first 10 eggs. Egg Number (EN90) and Weight (EW90) were recorded for each chicken during the first 90 days of laying. Egg Mass (EM) was measured for each chicken during the first 90 days of laying. 


\section{DNA extraction and primer design for three genes}

Chicken genomic DNA was extracted from the blood samples using a Norgen Biotek kit, then quantified utilizing a spectrophotometer (pg T80, UK), and the final concentration for polymerase chain reaction (PCR) reaction was 50-100 ng/ul (Table 1). PCR primers were designed with NCBI and primers.

Table 1. Detail information for the primers of the candidate genes (GnRHR, PRL, and HMGCR) used for the polymerase chain reaction reaction.

\begin{tabular}{|c|c|c|c|}
\hline Gene /ID & Location & Primers & $\begin{array}{l}\text { Product } \\
\text { size }\end{array}$ \\
\hline $\begin{array}{l}\text { GnRHR } \\
\text { NC_006097.4 } \\
\text { ID: } 427517\end{array}$ & Chromosome 10 & $\begin{array}{l}\text { F 5' CAGGGGACAGGGTGACCTA3' } \\
\text { R 5'GAGGACCACGAGGGATGTTC3' }\end{array}$ & $210 \mathrm{bp}$ \\
\hline $\begin{array}{l}\text { PRL } \\
\text { NC_006089.5 } \\
\text { ID: } 396453\end{array}$ & Chromosome 2 & $\begin{array}{l}\text { F5'TTTAATATTGGTGGGTGAAGAGAC3' } \\
\text { R 5'ATGCCACTGATCCTCGAAAACTC3' }\end{array}$ & 154 bp \\
\hline $\begin{array}{l}\text { HMGCR } \\
\text { NC_006127.4 } \\
\text { ID: } 395145\end{array}$ & Chromosome Z & $\begin{array}{l}\text { F 5'AGGGAACCTCCTGTGTTCCT3' } \\
\text { R 5'AATGGACTTCGACTTGTGGGA3' }\end{array}$ & $675 \mathrm{bp}$ \\
\hline
\end{tabular}

Table 2. The polymerase chain reaction program used for candidate genes.

\begin{tabular}{llllll}
\hline Gene & Pre - Denaturation & Denaturation & Annealing & Extension & Final Extension \\
\hline GnRHR & $95{ }^{\circ} \mathrm{C} / 5$ minutes & $95{ }^{\circ} \mathrm{C} / 45$ seconds & $59.9^{\circ} \mathrm{C} / 30$ seconds & $72{ }^{\circ} \mathrm{C} / 45$ seconds & $72{ }^{\circ} \mathrm{C} / 5$ minutes \\
\hline PRL & $95{ }^{\circ} \mathrm{C} / 5$ minutes & $95{ }^{\circ} \mathrm{C} / 45$ seconds & $54.9{ }^{\circ} \mathrm{C} / 30$ seconds & $72{ }^{\circ} \mathrm{C} / 45$ seconds & $72{ }^{\circ} \mathrm{C} / 5 \mathrm{minutes}$ \\
\hline HMGCR & $95{ }^{\circ} \mathrm{C} / 5$ minutes & $95{ }^{\circ} \mathrm{C} / 45$ seconds & $60{ }^{\circ} \mathrm{C} / 30$ seconds & $72{ }^{\circ} \mathrm{C} / 45$ seconds & $72{ }^{\circ} \mathrm{C} / 5$ minutes \\
\hline
\end{tabular}

GnRHR: Gonadotropin-Releasing-Hormone Receptor, PRL: Prolactin, HMGCR: 3-Hydroxy-3-Methylglutaryl-Coenzyme A Reductase.

Polymerase chain reaction amplification for the candidate genes

The PCR amplification was performed in $25 \mathrm{ul}$ reaction volumes, containing master mix $2 \times$ PCR primers and DNA (Promega, Madison, USA). As can be seen in Table 2, the program for all genes was done in 35 cycles. The amplified PCR products were separated by electrophoresis on $1.5 \%$ agarose in $1 \times$ Tris- Acetic EDTA(TAE) buffer, ethidium bromide at the voltage of 70 volts for 1 hour, and then were read with UV light from the transilluminator (Nippon Genetics European Union).

\section{Statistical analysis}

The data of chickens from three strains of SI, LB, and GM strain were collected. The numbers of birds were 150, 130, and 101 from SI, LB, and GM pullets strain, respectively. Data analysis for egg production were performed using PROC GLM in SAS (2004) and the following formula.

$$
Y_{i j}=\mu+S_{j}+e_{i j}
$$

Where, $Y_{i j}$ denotes observation, $\mu$ refers to general mean, $\mathrm{Sj}$ is the effect of strain, and $\mathrm{e}_{\mathrm{ij}}$ counts for random error. The student Newman keuls option was used to test the differences between the strains. In the current experiment, ANOVA test was used to find out the significance of the experiment results. In other words, the test helps to figure out whether the null hypothesis needs to be rejected or the alternate hypothesis can be accepted under probability $(\mathrm{p} \leq 0.01)$.

\section{RESULTS}

\section{The egg production}

The least-square means for egg production traits in the three strains of Lohmann Brown (LB), Gimmizah (GM), and Sinai (SI) are indicated in Table 3. The LB strain matured significantly younger $(\mathrm{p} \leq 0.01$ ) (in 147.5 days) than those of local GM and SI strains (Table 3). In addition, Sinai pullets matured earlier (in 156.6 days), compared to the Gimmizah strain (in 160.8 days). 
Lohmann Brown Pullets matured 13.3 days and 9.1 days earlier than the GM and SI pullets, respectively. Regarding ASM, there was a difference between the three strains, possibly due to genetic makeup. In a breeding program, ASM is a very important trait as it affects the properties of egg production.

The duration of laying the first 10 eggs (DU 10) is presented in Table 3. There was a highly significant difference $(\mathrm{p} \leq 0.01)$ between the strains ranging from 13.5 to 17.3 days. The required time to lay the first 10 eggs of LB pullets is shorter than SI and GM pullets. The SI strain indicated a decreased in DU 10, compared to the GM strain by 2.18 days. The average egg weight of the first 10 eggs in the LB strain was $51.12 \mathrm{~g}$, compared to $48.5 \mathrm{gm}$ in the GM strain. The SI strain indicated a decrease in the average egg weight of the first 10 eggs of $42.7 \mathrm{~g}$. The egg counts during the first 90 days were 62.45 , 45.07, and 43.27 for the LB, GM, and SI strains, respectively (Table 3). The Lohmann Brown strain had a highly significant EN90 than the GM and SI strains. On the other hand, there was no significant difference in EN90 between GM and SI strain.

The Total mean of LB strain indicated a highly significant $(\mathrm{p} \leq 0.01)$ increase in average egg weight during the first 90 days $(57.58 \mathrm{~g}$ ), compared to GM strain $(53.81 \mathrm{~g})$ and SI strain $(48.74 \mathrm{~g})$. The Gimmizah pullets had the highest egg weight, compared to the SI pullets in the first 90 days and the difference was significant $(\mathrm{p} \leq$ $0.01)$. Table 3 presents a highly significant difference ( $p \leq$ 0.01 ) between strains on egg mass during the first 90 days of laying. Pullets of LB strain produced significantly the largest egg mass, compared to the other pullet strain. The overall means of egg mass during the first 90 days were 3633.69, 2459.95, and $2099.19 \mathrm{~g}$ for LB, GM, and SI strain, respectively. The SI strain indicated a lower egg mass than the other strains.

Table 3. Least square means \pm Standard Error and analysis of variance for egg production traits in three strains of Lohman Brown, Gimmizah, and Sinai

\begin{tabular}{|c|c|c|c|c|}
\hline $\begin{array}{ll}\text { Trait } & \text { Strain } \\
\end{array}$ & GM & 'SI & LB & ANOVA \\
\hline Age \& sexual maturity & $160.89 \pm 2.22^{\mathrm{A}}$ & $156.66 \pm 1.01^{\mathrm{B}}$ & $147.50 \pm 0.69^{\mathrm{C}}$ & $* *$ \\
\hline Duration of layingthe first10 eggs & $17.30 \pm 0.73^{\mathrm{A}}$ & $15.12 \pm 0.21^{\mathrm{B}}$ & $13.59 \pm 0.25^{\mathrm{C}}$ & $* *$ \\
\hline Egg weight at first 10 eggs & $48.50 \pm 0.59^{\mathrm{B}}$ & $42.74 \pm 0.42^{\mathrm{C}}$ & $51.12 \pm 0.32^{\mathrm{A}}$ & $* *$ \\
\hline Egg number during first 90 days of laying & $45.07 \pm 2.53^{\mathrm{B}}$ & $43.27 \pm 0.84^{\mathrm{B}}$ & $62.45 \pm 1.18^{\mathrm{A}}$ & $* *$ \\
\hline Egg weight at first 90 days of laying & $53.81 \pm 0.81^{\mathrm{B}}$ & $48.74 \pm 0.79^{\mathrm{C}}$ & $57.58 \pm 0.53^{\mathrm{A}}$ & $* *$ \\
\hline Egg mass & $2459.95 \pm 156.80^{\mathrm{B}}$ & $2099.19 \pm 47.88^{\mathrm{C}}$ & $3633.69 \pm 87.09^{\mathrm{A}}$ & $* *$ \\
\hline
\end{tabular}

Different letters in each row mean significant differences $(\mathrm{p} \leq 0.05) .{ }^{* *}$ : significantly different between strains at $(\mathrm{p} \leq 0.001)$. GM: Gimmizah, SI: Sinai, LB: Lohman Brownç

\section{Polymerase chain reaction amplification for Prolactin gene}

The Prolactin gene located on Chromosome 2 is the candidate gene associated with increased egg production in chickens. The Polymerase Chain Reaction (PCR) was used to amplify the Prolactin gene fragments. The amplified product was $154 \mathrm{bp}$, indicating that the amplicon was Prolactin. For the SI strain, 5 bands appeared on lines 8, 22, 26, 64, and 70 (Figure 1). For the LB strain, five bands appeared on lines 9, 12, 14, 58, and 97 (Figure 2), and also for GM two bands appeared on lines 71 and 81 (Figure 2).

Polymerase chain reaction amplification for 3Hydroxy-3-methylglutaryl-coenzyme A reductase gene

As an important candidate gene affecting cholesterol metabolism, polymorphisms of the HMGCR gene and their associations have attracted much attention in mammals. The amplified product was 675 bp. For the SI strain, two bands were appeared on lines 8 and 22 (Figure 3), while, three bands appeared on lines 12, 14, and 97 for the LB strain (Figure 4), finally for GM strain only one band appeared on line 81 (Figure 4).

Polymerase chain reaction amplification for Gonadotropin-Releasing Hormone Receptor gene

Fragments were amplified using PCR. The amplified product was $210 \mathrm{bp}$, indicating that the amplicon was GNRHR. For SI strain, 5 bands were displayed on lines 8 , 22, 26, 64, and 71 (Figure 5). For the LB strain, 3 bands were appeared on lines 12, 14, and 97 (Figure 6). For the GM strain, 2 bands were appeared on lines 71 and 81 (Figure 6). The number of genes associated with economic characters was limited and few. 


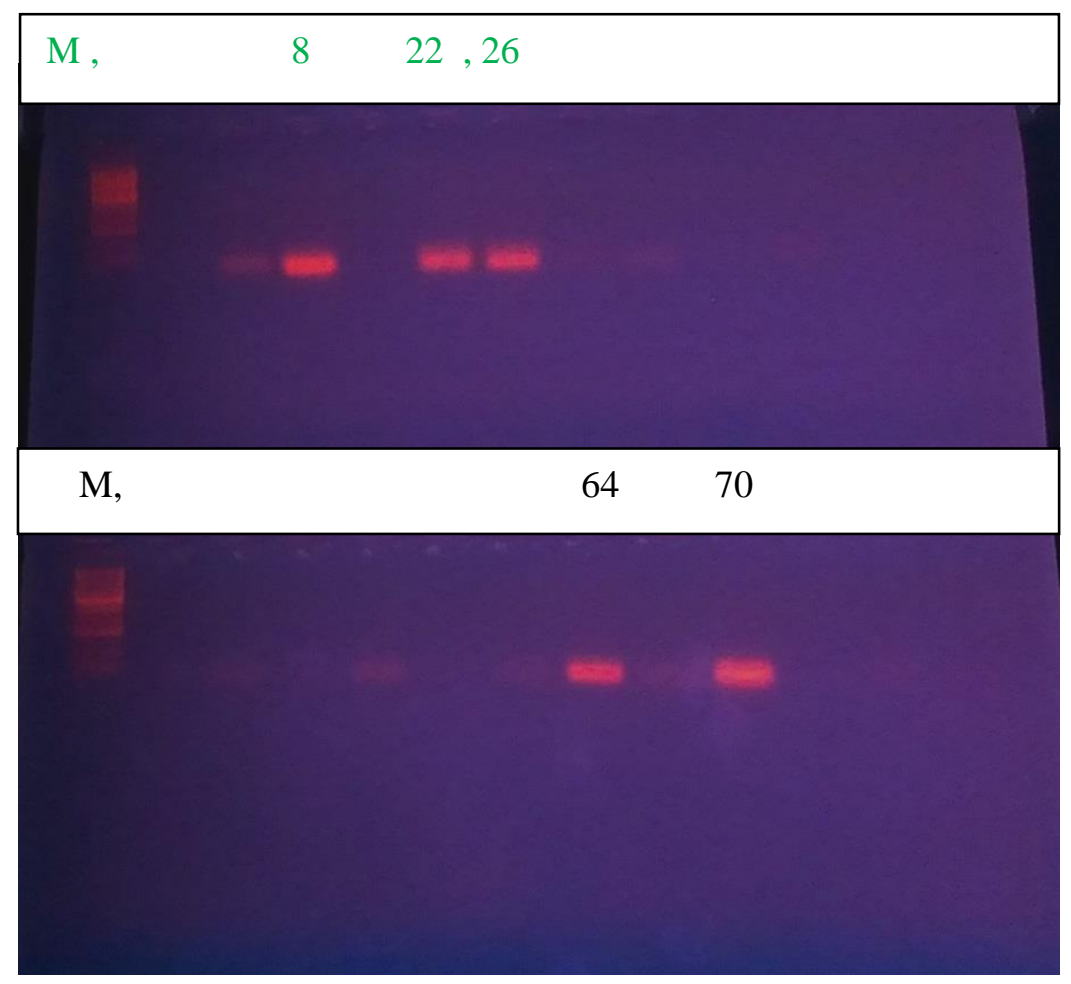

Figure 1. Polymerase chain reaction amplification gel image of the Prolactin gene of chicken (Sinai strain, $\mathrm{M}=1 \mathrm{~kb}$ ladder)

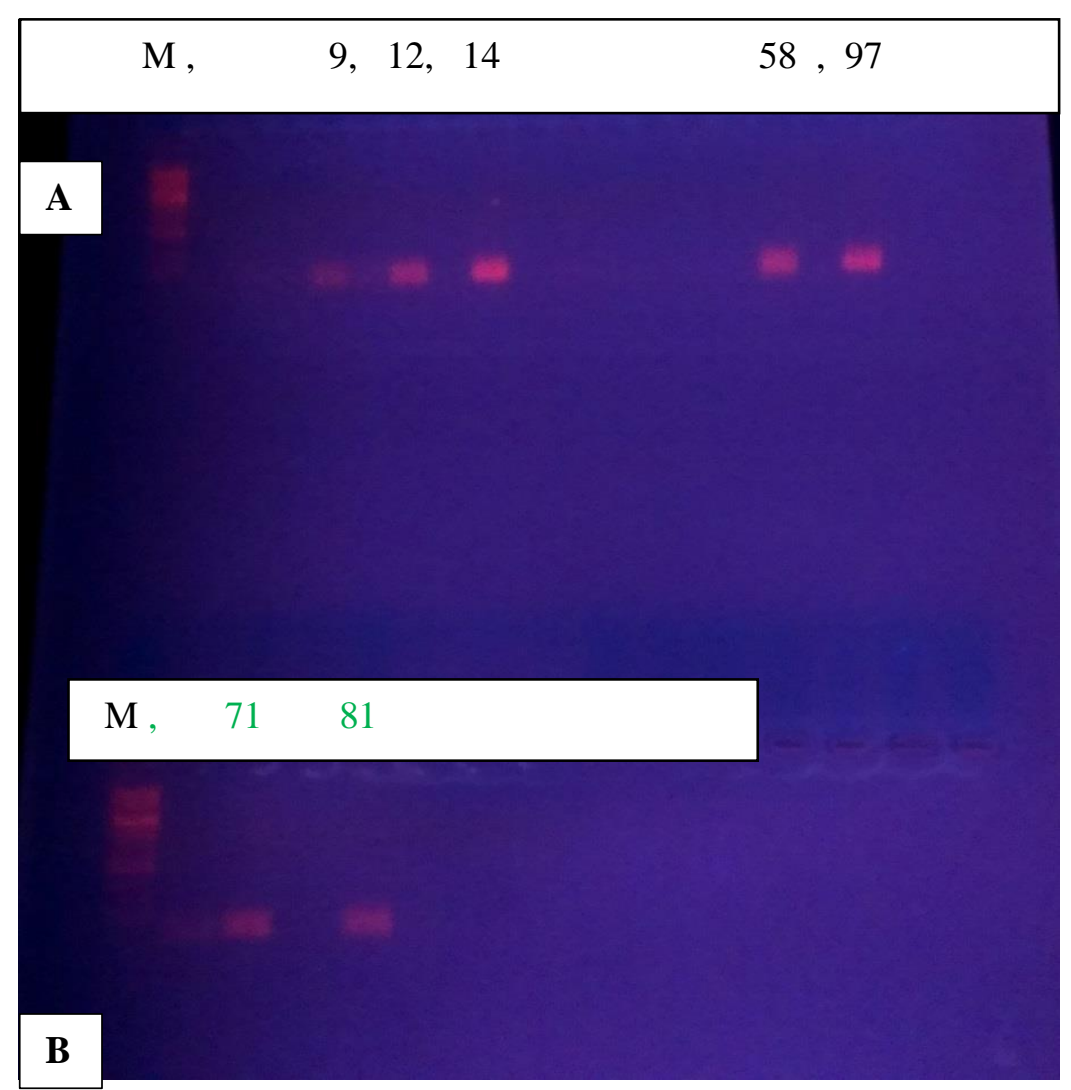

Figure 2. Polymerase chain reaction amplification gel image of the Prolactin gene of chicken (A: Lohmann Brown strain, B: Gimmizah strain, $\mathrm{M}=100 \mathrm{bp} 1 \mathrm{~kb}$ ladder) 


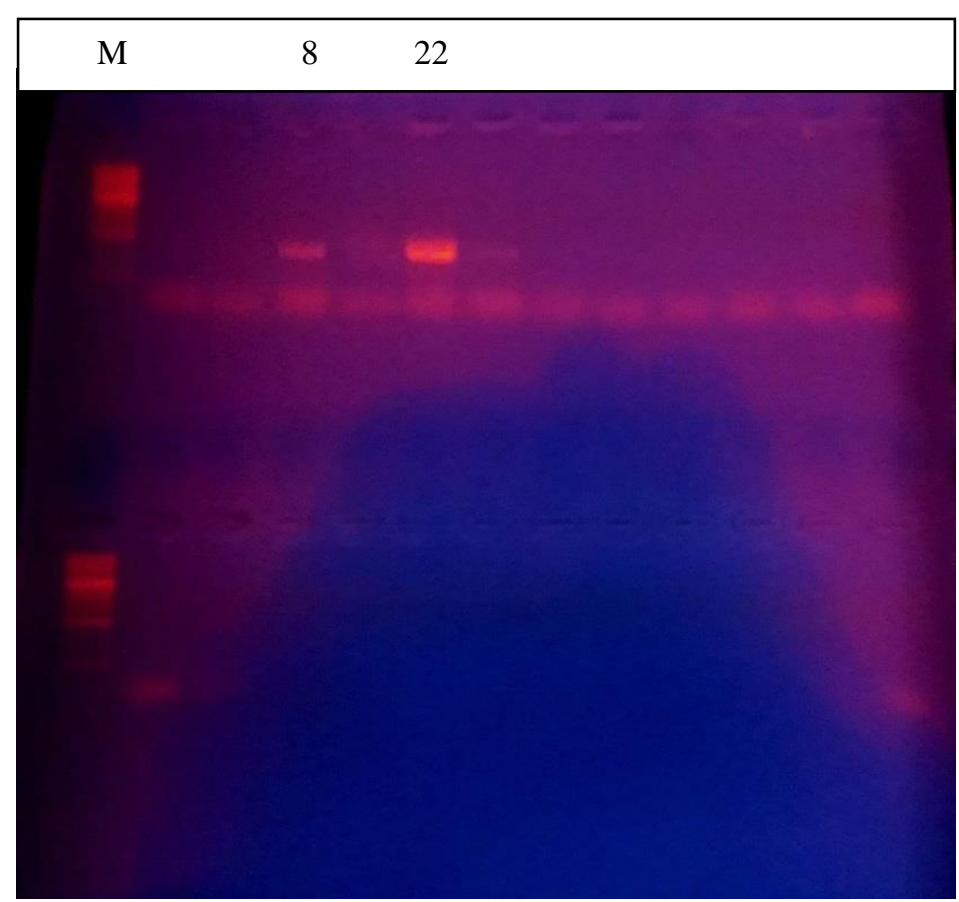

Figure 3. Polymerase chain reaction amplification gel image of the HMGCR gene of chicken (Sinai strain, M=1kb ladder)

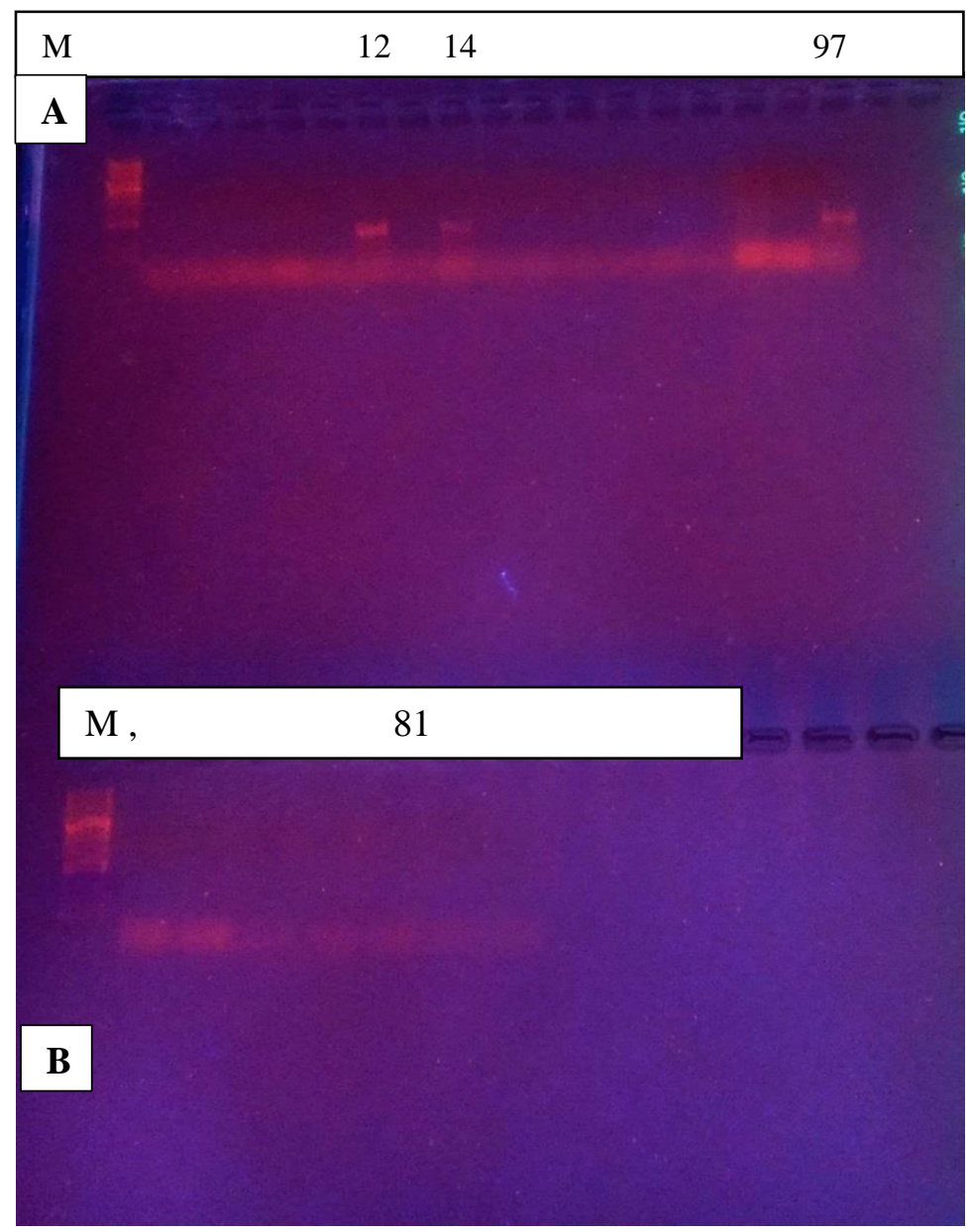

Figure 4. Polymerase chain reaction amplification gel image of the HMGCR gene of chicken. (A: Lohmann strain, B: Gimmizah strain, $\mathrm{M}=1 \mathrm{~kb}$ ladder) 


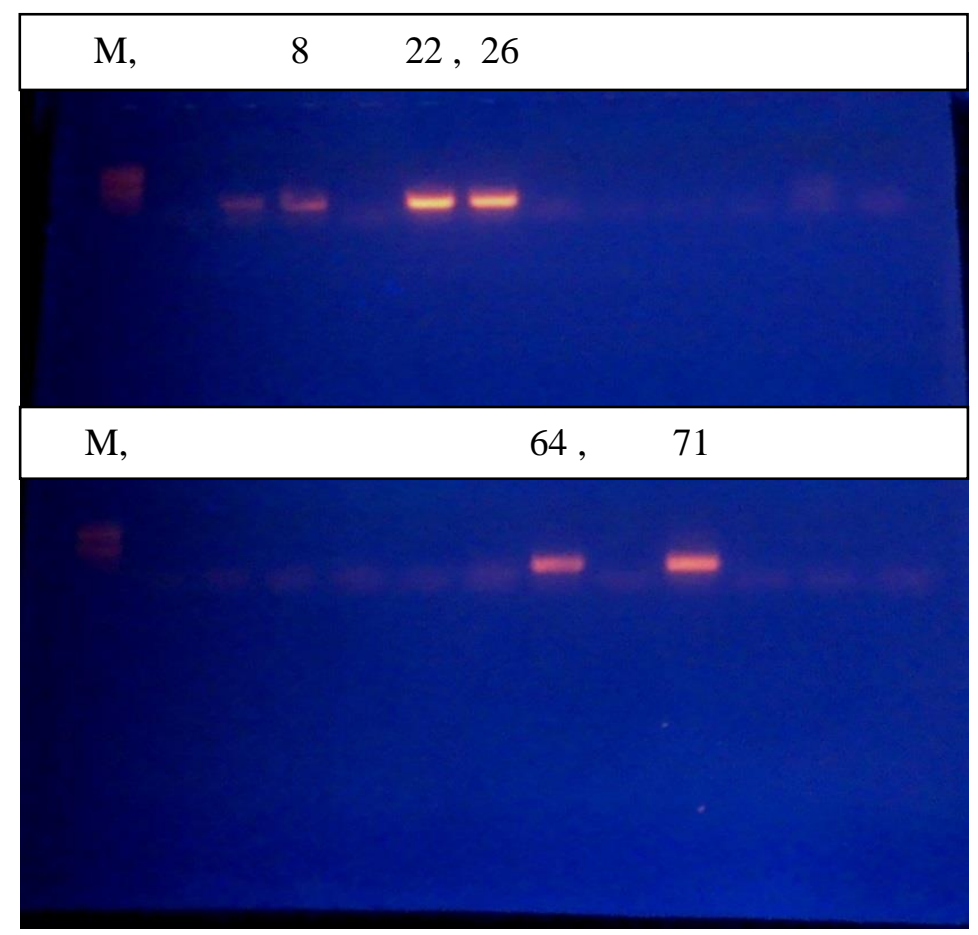

Figure 5. Polymerase chain reaction amplification gel image of the GNRHR gene of chicken (Sinai strain, M=100 bp)

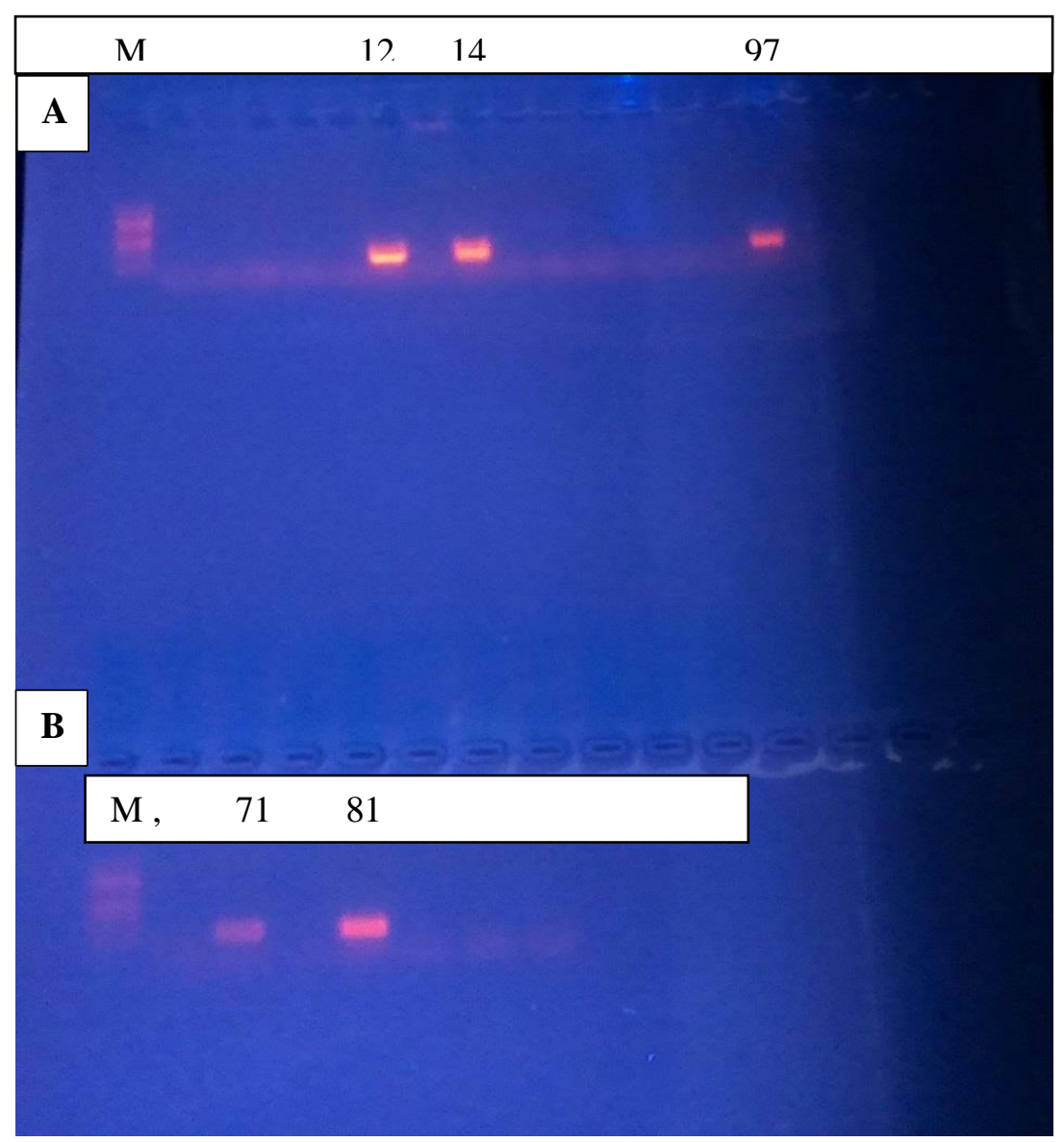

Figure 6. Polymerase chain reaction amplification gel image of the GNRHR gene of chicken (A: Lohmann Brown strain, B: Gimmizah strain, $\mathrm{M}=100 \mathrm{bp}$ ) 


\section{DISCUSSION}

In a breeding program, ASM is a really important trait as it affects the properties of egg production. The laying duration of the first 10 eggs (DU 10) is presented in Table 3. The ASM of different strains was within the range of 13.5-17.3 days, which supported the results of studies conducted by EL-Labban et al. (2011), Ghanem et al. (2012), and EL-Tahawy (2015).

The duration of laying in the first 10 eggs (DU 10) is presented in Table 3. There was a highly significant difference $(p \leq 0.01)$ between strains ranging from 13.5 to 17.3 days, which is in line with the previous studies reported by Bonekamp et al. (2010), and Taha et al. (2012). The number of eggs during the first 90 days was calculated as 62, 45, and 43 for LB, GM, and SI strains, respectively. The obtained results of maturity agreed with studies performed by Alicja Sobczak and Krzysztof, (2015), and EL-Tahawy (2015) that found the overall means of ASM 147.5 and 156.6 days for LB and SI strains, respectively. Present results in Table 3 were in agreement with those obtained by Bonekamp et al. (2010), and Alicja sobczak and Krzysztof (2015). The overall means of egg mass during the first 90 days were 3633.69, 2459.95, and $2099.19 \mathrm{~g}$ for LB, GM, and SI strains, respectively, which was consistent with the results reported by Soares et al. (2011), Alicja sobczak and Krzysztof (2015), and EL-Tahawy (2015).

Various studies have indicated that polymorphisms in the chicken PRL gene of different breeds are associated with egg production (Bhattacharya et al., 2011; Cui et al., 2006). Prolactin regulates important physiological functions, such as reproductive and homeostatic effects. Elkins et al. (2000), and Zhang et al. (2012) found that the polymorphism of the PRL gene was significantly associated with egg production traits in chickens and that it is a strong candidate gene affecting egg production traits.

The HMGCR was considered to be a logical candidate gene for cholesterol metabolism, as HMGCR is the rate-limiting enzyme in cholesterol synthesis (XU et al., 2010). The GNRHs are responsible for the development and function of the reproductive properties in avian (Bedecarrats et al., 2006).

\section{CONCLUSION}

In a breeding program, age at sexual maturity (ASM) is a very important trait as it affects the properties of egg production. Based on the obtained results of the current study, ASM was significantly different among the three strains of Lohmann Brown, Sinai, and Gimmizah possibly due to the genetic makeup. The Lohmann Brown strain can be used to mature earlier and have a higher egg number than Gimizah and Sinai strains during the first 90 days. The performed PCR indicated some bands for Prolactin, 3-Hydroxy-3-methylglutaryl-coenzyme A reductase, and Gonadotrophin Releasing Hormone Receptor genes. The authors of the present study aim to complete their works by examining gene expression using RT-PCR.

\section{DECLARATION}

\section{Authors' contribution}

El-Tahawy collected the samples and designed research. Abdel-Rahman was responsible for DNA extraction, PCR, and participated in writing. All authors checked and confirmed the final draft of manuscript.

\section{Acknowledgments}

Research supported by the Science and Technology Development Fund (STDF, 2418).

\section{Competing interests}

The authors of present study did not have any conflict of interests.

\section{REFERENCES}

Alameri MS, Al-anbari EH, and Razuki WM (2019). Association the gonadotropin-releasing hormone receptor (GNRHR) gene polymorphisms with egg production traits in Iraqi local brown chicken.Biochemical. Cellular. Archives, 19(1): 13731380.

DOI: https://www.doi.org/10.35124/bca.2019.19.1.13 $\underline{73}$

Alicja Sobczak A, and Krzysztof K (2015). The effect of a probiotic preparation containing bacillus subtilisatccpta- 6737 on egg production and physiological parameters of laying hens. Annual Animal science, 15(3): 711-723. DOI: https://www.doi.org/10.1515/aoas-2015-0040

Bedecarrats GY, Shimizu M, and Guemene D (2006). Gonadotropin-releasing hormones and their receptors in avian species. PoultaryScience, 43: 199-214. DOI: https://www.doi.org/10.2141/jpsa.43.199

Bhattacharya TK, Chatterjee RN, Dange M, and Bhanja SK (2019). Polymorphisms in GnRHI and GnRHII genes and their association with egg production and egg quality traits in chicken. 
British Poultry Science, 60: 187-194. DOI: https://www.doi.org/10.1080/00071668.2019.157550 $\underline{5}$

Bhattacharya TK, Chatterjee RN, Sharma RP, Rajkumar U, Niranjan M, and Reddy BLN (2011). Association of polymorphism in the prolactin promoter and egg quality traits in laying hens. British Poultry Science, 52(5): 551-557. DOI: https://www.doi.org/10.1080/00071668.2011.617727

Bonekamp RP, Lemme RTA, Wijttend PJA, and Sparla JKW (2010). Effect of amino acids on egg number and egg mass of brown (heavy breed) and white (light breed)laying hens. Poultry Science, 89: 522-529. DOI: https://www.doi.org/10.3382/ps.2009-00342

Carolsfeld J, Powell J, Park M, Fischer W, Craig A, Chang J, Rivier J, and Sherwood N (2000). Primary structure and function of three gonadotropin releasing hormones, including a novel form, from an ancient teleost, herring. Endocrinology, 141: 505-512. DOI: https://www.doi.org/10.1210/endo.141.2.7300

Chasman D, Posada D, Subrahmanyan L, Cook N, Stanton V, and Ridker P (2004). Pharmacogenetic study of statin therapy and cholesterol reduction. The Journal of the American Medical Association, 291: 28212827.

DOI:

https://www.doi.org/10.1001/jama.291.23.2821

Chen X,Wang X, Li Z, Kong L, Liu G, Fu J, and Wang A (2012). Molecular cloning tissue expression and protein structure prediction of the porcine 3-hydroxy3-methylglutaryl coenzyme a reductase (HMGR) gene Gene, 495: 170-177. DOI: https://www.doi.org/10.1016/j.gene.2011.12.051

Cui J, Du H, Liang Y, Deng X, Li N, and Zhang X (2006). Association of polymorphisms in the promoter region of chicken prolactin with egg production. Poultry Science, $\quad 85(1)$ : $\quad 26-31 . \quad$ DOI: https://www.doi.org/10.1093/ps/85.1.26

Dunn IC, Miao YW, Morris A, and Romanov MN (2004). A study of the association between genetic markers in candidate genes and reproductive traits in one generation of a commercial broiler breeder hen population. Heredity, 92: 952-957. DOI: https://www.doi.org/10.1038/sj.hdy.6800396

Elkins PA, Christinger HW, Sandowski Y, Sakal E, Gertler A, de Vos AM, and Kossiakoff AA (2000). The ternary complex between placental lactogen and the extracellular domain of the prolactin receptor. Nature . Structural. Biology, 7: 808-815. DOI: https://www.doi.org/10.1038/79047

EL-Labban AM, Iraqi MM, Hanafi MS, and Heba AH (2011). Estimation of the genetic and non-genetic parameter for egg production trait in a local strain of chicken. Livestock Research for rural development 23: Article ID \#10. Available at: http://www.lrrd.org/lrrd23/1/ella23010.htm
EL-Tahawy WS (2015). Effect of strain on some growth and egg production traits between two strains of chicken under Egyptian environmental conditions. Egyptian Poultry Science, 35: 1137-1145.

Fatemi SA, Mehrabani- Yeganeh H, Nejati- Javaremi A, and Niknafs SH (2012). Association of neuropeptide $\mathrm{Y}$ and gonadotrophin-releasing hormone receptor gene SNPs with breeding value for growth and egg production traits in Mazandaran native chickens Genetics and Molecular Research, 11(3): 2539-2547. DOI: https://www.doi.org/10.4238/2012.july.10.9

Ghanem HH, EL-Tahawy WS, Attia YA, and Nawar AN (2012). Devolping A 3 - way cross of chickens to improve egg production traits. Egyptian Poultry Science, 32: 547-560. Available at: https://scholar.google.com/scholar?cluster $=94143989$ $06143841801 \& \mathrm{hl}=\mathrm{en} \&$ as $\mathrm{sdt}=2005 \&$ sciodt $=0,5$

Goldstein J, and Brown M (1990). Regulation of the mevalonate pathway. Nature, 343: 425-430. DOI: https://www.doi.org/10.1038/343425a0

Han C, An G, and Du X (2014). Three novel single nucleotide polymorphisms of the 3-hydroxy-3methylglutaryl coenzyme a reductase gene associated with egg-production in chicken. Folia Biologica (Kraków), 62: 203-209. DOI: https://www.doi.org/10.3409/fb62_3.203

Henriksen J, Rowat AC, Brief E, Hsueh YW, Thewalt JL, Zuckermann MJ, and Ipsen JH (2006). Universal behavior of membranes with sterols. Biophysical. Journal, 90: 1639-1649. DOI: https://www.doi.org/10.1529/biophysj.105.0676 $\underline{52}$

Istvan E, and Deisenhofer J (2000). The structure of the catalytic portion of human HMG-CoA reductase Biochimica et Biophysica Acta, 1529(1-3): 9-18. DOI: $\quad$ https://www.doi.org/10.1016/s13881981(00)00134-7

Kuo Y, Shiue YL, Chen CF, Tang PC, and Lee YP (2005). Proteomic analysis of hypothalamic proteins of high and low egg production strains of chickens Theriogenology, 64:

1490-1502. DOI: https://www.doi.org/10.1016/j.theriogenology.2 005.03 .020

Liu WJ, Sun DX, Yu Y, Li G, Tang SQ, Zhang Y, and Wang YC (2010). Association of Janus kinase 2 polymorphisms with growth and reproduction traits in chickens. Poultry Science, 89(12): 2573-2579. DOI: https://www.doi.org/10.3382/ps.2010-00988

Macreadie I, Johnson G, Schlosser T, and Macreadie P (2006). Growth inhibition of Candida species and Aspergillus fumigatus by statins FEMS Microbiology Letters, 261(1): 9-13. https://www.doi.org/10.1111/j.15746968.2006.00370.x 
SAS (2004). USM, S Guide: Statistics SAS, Institute inc. Cary, NS, U.S.A.

Sun YM, Dunn IC, Baines E, Talbot RT, Illing N, Millar RP, and Sharp PJ (2001). Distribution and regulation by oestrogen of fully processed and variant transcripts of gonadotropin releasing hormone I and gonadotropin releasing hormone receptor mRNAs in the male chicken. Journal of Neuroendocrinol, 13: 3749. DOI: https://www.doi.org/10.1111/j.1365$\underline{2826.2001 .00587 . x}$

Sonez M, Sonez C, Mugnnaini M, and Haedo M (2010). Effects of differential pulse frequencies of chicken gonadotrophin- releasing hormone -1(cGnRH-1) on laying hen gonadotrope responses in vitro. Biotechnology Histochemistry, 85: 355-363. DOI: https://www.doi.org/10.3109/105202909033687 $\underline{74}$

Soares ML, Lopes JC, Brito NV, and Carualherira J (2011). Characterization of growth and egg production of two Portuguese autochthonous chicken breed pretalusitanica and amarela. The $62^{\text {nd }}$ annual meeting of the European Association for Animal production-August $29^{\text {th }}$ to September $2^{\text {nd }}$, Stavanger, Norway. https://www.doi.org/10.4081/ijas.2015.3566

Taha AE, Abdel ghany FA, and Sharaf MM (2012). Strain effect on some productive and reproductive performance traits of local improved Egyptian and Canadian chickens. Journal of animal and feed research, 2: 292-300. Available at: https://www.ojafr.ir/main/attachments/article/87/OJA FR,\%20B55,\%20292-300,\%202012.pdf
Xu N, Taylork D, Azziz R, and Goodarzi MO (2010). Variants in the HMG-CoA reductase (HMGCR) gene influence component phenotypes in polycystic ovary syndrome. Fertility. Sterility, 94: 255-260. DOI: https://www.doi.org/10.1016/j.fertnstert.2009.01.158

Van Doren M, Broihier H, Moore L, and Lehmann R (1998). HMG-CoA reductase guides migrating primordial germ cells. Nature, 396: 466-469. DOI: https://www.doi.org/10.1038/24871

Wei Y, Zhu S, Zhang S, Han R, Tian Y, Sun G, and Kang $X$ (2012). Two novel SNPs of the 3-hydroxy-3methylglutaryl coenzyme a reductase (HMGR) gene associated with growth and meat quality traits in the chicken. Genetics and Molecular Research, 11: 47654774.

DOI: https://www.doi.org/10.4238/2012.November.12.10

Wolc A, Arango J, Settar P, O'Sullivan NP, and Dekkers JC (2011). Evaluation of egg production in layers using random regression models. Poultry Science, 90(1): 30-34. DOI: https://www.doi.org/10.1016/j.fertnstert.2009.01.158

Zhang L, Li D, Liu Y, Wang Y, Zhao X, and Zhu Q (2012). Genetic effect of the prolactin receptor gene on egg production traits in chickens Genetics and molecular research, 11: 4307-4315. DOI: https://www.doi.org/10.4238/2012.October.2.1

Zhuang L, Ning Y, Yiyuan Y, Guangqi L, Aiqiao L, Guiqin W, and Congjiao S (2019). Genome-wide association analysis of egg production performance in chickens across the whole laying period BMC, Pp. 19. DOI: https://www.doi.org/10.1186/s12863-0190771-7. 